\title{
Factors Affecting Student Satisfaction with Blended Instruction for the "Digital Image Fundamental" Course at Chengdu University
}

\author{
Xiang Chaochu and Somsit Duangekanong
}

\begin{abstract}
This research evaluated the factors that significantly influenced student satisfaction with blended instruction in the "Digital Image Fundamental" course for the animation major at Chengdu University. The conceptual framework assumed causal connections among five vital latent variables. The quantitative analysis included data from 210 participants selected through multistage sampling. After the data collection, confirmatory factor analysis and structural equation model were employed to verify all the hypotheses for the framework constructs. Each latent variable had a significant impact on the connected one, and course structure demonstrated the strongest influence on satisfaction; hence, the five hypotheses were verified. Based on the findings, it is recommended that the office of academic affairs of animation departments at public universities consider the essential factors of student satisfaction for blended instruction schema to improve satisfaction levels for undergraduates with an animation major.
\end{abstract}

Index Terms-Blended instruction, digital image fundamental, perceived ease of use, perceived usefulness, attitude, course structure, satisfaction.

\section{INTRODUCTION}

\section{A. Background of the Research}

Blended instruction is a form of education that combines face-to-face tutoring elements with online teaching components [1]. It can facilitate positive independent studying and reduce classroom time, both of which are great advantages, in comparison to approaches that use only face-to-face or online instruction [2]. Nevertheless, at the university level in China, especially for undergraduate students with an animation major, the current method of blended teaching presents various challenges [3], such as overemphasizing superficial form and neglecting the content design of the course, as well as lacking distinction between hybrid and online learning.

In June 2020, the researcher evaluated the attitudes of 1,019 animation majors students from three representative public universities in the Chengdu region who received online instruction for an entire semester. Among them, 23\% of the students were extremely satisfied with the quality of online instruction, $36 \%$ were almost satisfied, $11 \%$ held a

Manuscript received August 23, 2021; revised September 14, 2021.

Xiang Chaochu is with Assumption University, Thailand (e-mail: 254494839@qq.com).

Somsit Duangekanong is with the Graduate School of Business and Advanced Technology Management, Assumption University of Thailand (e-mail: singapore_ben@yahoo.co.uk). neutral attitude, $23 \%$ were not very satisfied, and $7 \%$ were very dissatisfied. Only $59 \%$ of the students exhibited a positive attitude.

After the massive online education period during the COVID-19 pandemic, many instructors pointed out a need to strengthen the quality of blended education, and several universities introduced support for the academic exploration of blended education models. Student satisfaction is the most essential latent variable for this realm of research.

The animation major is a representative sample of the art design major at the university level. The animation major at Chengdu University has great influence across China, and "Digital Image Fundamental" is a vital core professional course within the curriculum.

\section{B. Research Questions}

1) What factors of blended instruction should educational practitioners pay attention to, in order to improve student satisfaction and learning efficiency of animation majors?

2) What is the mechanism behind the interaction of satisfaction with acceptance of blended instruction among undergraduates in the animation major?

3) What factors influence students' acceptance of blended instruction and facilitate learning achievement for undergraduates in the animation major?

\section{Research Objectives}

1) Determine the factors that influence student satisfaction with blended instruction in the "Digital Image Fundamental" course for the animation major at Chengdu University.

2) Estimate the correlations between the other latent variables that significantly affect satisfaction.

3) Suggest additional directions of research on influencers of students' acceptance of blended instruction and facilitate better learning outcomes for undergraduates in the animation major.

\section{Significance of the Research}

This research identifies causal correlations among the influencers of student satisfaction, which can help instructors improve the efficacy of blended instruction to increase the learning performance and achievement of animation undergraduate students. Understanding student satisfaction is an essential part of examining whether students accept a particular teaching method or instructional technology. Therefore, it is important to shed light on the components of student satisfaction with blended instruction in animation courses at the university level. 


\section{LITERATURE REVIEW}

\section{A. Blended Instruction}

Blended instruction can be defined as a form of learning approach that combines the educational components of traditional classroom instruction with online studying resources [4]. A certain percentage of students have reported feeling more satisfied and perceiving greater efficiency with the blended instructional process compared to conventional classroom approaches or online teaching individually, when the advantages for online and offline education are integrated [5]. Blended instruction can enhance positive autonomous learning behavior and minimize synchronous classroom time, making the course structure (CS) more convenient and adaptable than traditional or purely online courses [6]. CS is an essential part of blended instruction, including pre-class previews, in-course learning, and after-class intensive reviews on the online and offline platforms, conducted in a way to achieve optimal student satisfaction [7].

\section{B. Perceived Ease of Use}

Davis defined PEOU as the extent to which an individual believes that utilizing a particular system is effortless [8]. The term can be applied to the perceptions of university students regarding whether a particular digital education technology is efficient [9]. Namely, in this research, it describes the degree to which a student thinks it is easy to engage in an online or hybrid education system [10]. According to social scientists, PEOU is related to an individual's behavior and inclination toward using target systems [11]. Moreover, it can weaken the risk perceptions related to technology utilization processes [12].

H1: PEOU has a significant effect on perceived usefulness (PU).

H3: PEOU has a significant effect on attitude.

\section{Perceived Usefulness}

Furthermore, Davis explained that PU is the extent to which individuals are convinced that employing a particular system facilitates their learning performance [8]. In other words, it is a measure of to what extent university students believe that using a learning system helps in improving their study performance [13]. Previous research revealed that a high degree of PU generally contributes to a user-achievement correlation [14]. In education, PU demonstrated to have benefits in the use of online resources at a precise time and place to promote and reform learning [15].

H2: PU has a significant effect on attitude.

\section{Attitude}

Attitude refers to positive or negative experiences of students with blended instruction at the emotional or psychological level [16]. It is an individual's determined psychological intention toward a particular object [17]. Numerous researchers found that attitude is a vital indicator of students' acceptance of a particular education technology [18]. Additionally, attitude can be considered to influence one's psychology in terms of learning motivation in educational settings [19].

H4: Attitude has a significant effect on satisfaction.

\section{E. Course Structure}

CS is a crucial independent variable that has a significant impact on student satisfaction [20]. In hybrid education, it is essential for instructors to appropriately coordinate online and face-to-face course components [21]. Several researchers conducted factor analyses of questionnaire responses in qualitative research on blended instruction to show that CS was an obvious and essential influencer [22].

H5: CS has a significant effect on satisfaction.

\section{F. Satisfaction}

Satisfaction reflects students' positive cognitions about their blended instruction experiences [16]. Locke described that satisfaction is a category of psychological behavior intention that is connected to an individual's subjective estimate of the quality or capability of a certain relationship [23]. According to psychologists, satisfaction is deeply connected with cheerful valuations about pleasantness originating from positive cognitions [24]. Perceived satisfaction is frequently used as an indicator to estimate the accomplishments or unsuccessful utilization of a blended instruction system and primarily demonstrates students' perception of a digital learning system and comfort level in engaging with it [25].

\section{ReSEARCh Methodology AND MAterials}

\section{A. Conceptual Framework}

The conceptual framework of this research is developed from previous literature based on the technology acceptance model (TAM). Nagy (2018) confirmed the interaction mechanism correlation of four latent variables: PEOU, PU, attitude (ATT), and satisfaction (SAT) [16]. In addition, Harsasi and Sutawijaya (2018) determined that CS has a significant influence on student satisfaction [20]. Hence, the conceptual framework of this research is illustrated in Fig. 1.

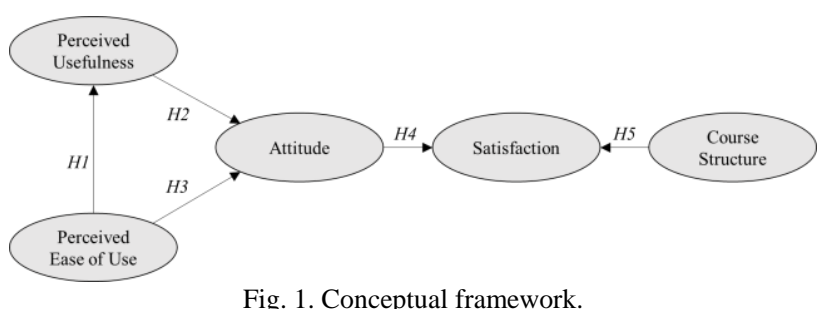

\section{B. Research Methodology}

A quantitative survey was conducted using an in-person questionnaire. The questionnaire was distributed among animation major undergraduate students at Chengdu University who had already taken the "Digital Image Fundamental" course and had synchronous blended instruction experience. The survey comprised three parts: a screening question, demographic information, and five-point Likert scale items for the variables.

For the content validity of the research instrument, four specialists with a Ph.D. in education and almost 10 years of experience in giving blended instruction were invited to perform item-objective congruence to examine the objectives advanced by the scale items developer for this research. 
Based on the recommendations of Isaac and Michael (1995), 30 participants were required for the pilot test to achieve a suitable scale [26]. Therefore, the researcher selected 30 target students to take the pilot test and examined the internal consistency reliability using to the Cronbach's Alpha coefficient.

After the pilot test, the in-person questionnaires were circulated to 210 participants from the target university. The data were analyzed using IBM SPSS Statistics 24.0 and AMOS Graphics 18.0. In addition, confirmatory factor analysis (CFA) was applied to examine the factor loading, t-value, composite reliability (CR), average variance extracted (AVE), and discriminant validity. Structural equation modeling (SEM) was used to verify the hypothesis results and examine the direct, indirect, and total effects of the relationships between latent variables.

TABLE I: RESEARCH INSTRUMENT GRID

\begin{tabular}{|c|c|c|}
\hline Variable & Indicator & Source \\
\hline PEOU1 & The blended instruction system is easy for me. & \multirow{6}{*}{$\begin{array}{l}\text { Sangjo et } \\
\text { al. } \\
(2015)\end{array}$} \\
\hline PEOU2 & $\begin{array}{l}\text { It is easy to study utilizing the blended } \\
\text { instructional system. }\end{array}$ & \\
\hline PEOU3 & $\begin{array}{l}\text { I clearly understand how to take blended } \\
\text { instruction. }\end{array}$ & \\
\hline PEOU4 & $\begin{array}{l}\text { I find blended instruction inflexible to interact } \\
\text { with. }\end{array}$ & \\
\hline PEOU5 & $\begin{array}{l}\text { It is not easy for me to become skilled at using } \\
\text { blended instruction. }\end{array}$ & \\
\hline PEOU6 & I find blended instruction easy to adapt to. & \\
\hline PU1 & $\begin{array}{l}\text { Blended instruction helps me improve and } \\
\text { organize my studying better. }\end{array}$ & \multirow{5}{*}{$\begin{array}{l}\text { Manzano } \\
\text { et al } \\
(2009)\end{array}$} \\
\hline PU2 & $\begin{array}{l}\text { Blended education enhances the presentation of } \\
\text { my work enough to justify the extra effort. }\end{array}$ & \\
\hline PU3 & $\begin{array}{l}\text { Most studying that the blended instruction can } \\
\text { be used for, I can do just as well myself. }\end{array}$ & \\
\hline PU4 & $\begin{array}{l}\text { Blended instruction allows me to do more } \\
\text { efficient work. }\end{array}$ & \\
\hline PU5 & $\begin{array}{l}\text { Blended instruction makes my studying more } \\
\text { productive. }\end{array}$ & \\
\hline ATT1 & $\begin{array}{l}\text { I am afraid using the blended instruction system } \\
\text { because I might make errors in some way. }\end{array}$ & \multirow{6}{*}{$\begin{array}{l}\text { Fokides } \\
(2017)\end{array}$} \\
\hline ATT2 & $\begin{array}{l}\text { I hesitate to use the blended instruction system } \\
\text { because I might look stupid. }\end{array}$ & \\
\hline ATT3 & $\begin{array}{l}\text { I don't feel hesitant while using the blended } \\
\text { instruction system because it is suitable for me. }\end{array}$ & \\
\hline ATT4 & $\begin{array}{l}\text { The blended instruction makes me feel } \\
\text { uncomfortable or nervous. }\end{array}$ & \\
\hline ATT5 & $\begin{array}{l}\text { I hesitate to use the blended instruction system } \\
\text { owing to fear of making mistakes I can't correct. }\end{array}$ & \\
\hline ATT6 & Using blended instruction scares me. & \\
\hline $\mathrm{CS} 1$ & $\begin{array}{l}\text { The course material for the blended instruction } \\
\text { is presented in a good structure. }\end{array}$ & \multirow{4}{*}{$\begin{array}{l}\text { Harsasi } \\
\& \\
\text { Sutawijy } \\
\text { ay }(2018)\end{array}$} \\
\hline $\mathrm{CS} 2$ & $\begin{array}{l}\text { The learning objectives in blended instruction } \\
\text { have been conveyed properly. }\end{array}$ & \\
\hline $\mathrm{CS} 3$ & $\begin{array}{l}\text { The material in the blended instruction has been } \\
\text { arranged in a logical sequence and is } \\
\text { understandable. }\end{array}$ & \\
\hline CS4 & $\begin{array}{l}\text { The structure of the material in the blended } \\
\text { instruction already covers all the material I need } \\
\text { to learn in one subject. }\end{array}$ & \\
\hline SAT1 & $\begin{array}{l}\text { I am satisfied with using the blended instruction } \\
\text { system as a learning instrument. }\end{array}$ & \multirow{5}{*}{$\begin{array}{l}\text { Al-Azaw } \\
\text { ei \& } \\
\text { Lundqvis } \\
\text { t (2015) }\end{array}$} \\
\hline SAT2 & $\begin{array}{l}\text { I am satisfied with using the blended instruction } \\
\text { system functions. }\end{array}$ & \\
\hline SAT3 & $\begin{array}{l}\text { I am satisfied with my decision to take this } \\
\text { course via blended education. }\end{array}$ & \\
\hline SAT4 & $\begin{array}{l}\text { If I have an opportunity to take another course } \\
\text { via blended education, I will gladly do so. }\end{array}$ & \\
\hline SAT5 & $\begin{array}{l}\text { I feel that blended education has served my } \\
\text { needs well. }\end{array}$ & \\
\hline
\end{tabular}

Source: Created by the author.

\section{Participants and Sample Size}

The participants of this research comprised all Chinese animation major undergraduate students at Chengdu University, which totaled 390 individuals. According to Halabí and Mora-Esquivel (2017), the suitable sample size for SEM is 200 individuals [27]. For this investigation, 388 respondents were targeted, and after the screening and stratified sampling process, 210 participants were selected as the final sample.

\section{Sampling Technique}

The students were divided into four sample units based on their academic year. Multistage sampling strategies were conducted in two phases. Initially, the researcher performed judgmental sampling to select 360 undergraduate animation major students who had already taken the target course and had sufficient blended instruction experience. In addition, stratified random sampling was used to choose 210 students as the final sample, as shown in Table I.

TABLE II: THE SAMPLE UNITS AND SUB-SAMPLE SIZE

\begin{tabular}{llll}
\hline \hline \multirow{3}{*}{ Target University } & $\begin{array}{l}\text { Sample } \\
\text { Unit }\end{array}$ & $\begin{array}{l}\text { First Level } \\
\text { Sample Size } \\
(\mathrm{N}=360)\end{array}$ & $\begin{array}{l}\text { Secondary } \\
\text { Level Sample } \\
\text { Size }(\mathrm{N}=210)\end{array}$ \\
\hline \multirow{5}{*}{ Chengdu University } & Freshman & 85 & 50 \\
& Sophomore & 90 & 53 \\
& Junior & 93 & 54 \\
& Senior & 92 & 53 \\
\hline \hline \multicolumn{5}{c}{ Source: Created by the author. }
\end{tabular}

\section{RESUlTS AND DiscUSSION}

\section{A. Demographic Information}

The demographic information of participants is summarized in Table II. The male respondents represented $32.86 \%$ of the total, whereas the female respondents were $63.40 \%$. The student distribution by academic year was as follows: $22.86 \%$ freshmen, $26.19 \%$ sophomores, $26.19 \%$ juniors, and $24.76 \%$ seniors. Finally, concerning concentration within the major, $9.52 \%$ students selected 2D animation, $21.43 \%$ 3D animation, $4.29 \%$ experimental animation, and $41.90 \%$ comic design, whereas $19.86 \%$ were still waiting for their major direction selection procedure.

TABLE III: DEMOGRAPHIC INFORMATION PROFILE

\begin{tabular}{llll}
\hline \hline \multirow{2}{*}{ Demographic Information $(\mathbf{N}=\mathbf{2 1 0})$} & Frequency & Percentage \\
\hline \multirow{2}{*}{ Gender } & Male & 69 & $32.86 \%$ \\
& Female & 141 & $67.14 \%$ \\
\hline \multirow{2}{*}{ Academic } & Freshman & 48 & $22.86 \%$ \\
Years & Juphomore & 55 & $26.19 \%$ \\
& Senior & 55 & $26.19 \%$ \\
& 2D Animation & 52 & $24.76 \%$ \\
\multirow{3}{*}{$\begin{array}{l}\text { Major } \\
\text { Direction }\end{array}$} & 3D Animation & 20 & $9.52 \%$ \\
& Experimental Animation & 9 & $21.43 \%$ \\
& Comic & 88 & $4.29 \%$ \\
\hline \hline
\end{tabular}

Source: Created by the author. 


\section{B. Confirmatory Factor Analysis (CFA)}

Confirmatory factor analysis (CFA) was conducted for the data analysis. Lewis-Beck and several specialists described CFA as a multivariate statistical analysis procedure employed to synchronously examine multiple hypotheses that together construct an estimation matrix [28]. The significance of the factor loading for each observed variable indicates the goodness of fit to the research model [29]. As Table III shows, in the statistical results obtained using AMOS, the chi-square value to degree of freedom (CMIN/DF) was 1.151, which was below the threshold 3.000 [30]; the goodness-of-fit index (GFI) was just equal to the threshold 0.900 [31]; the adjusted goodness-of-fit index (AGFI) was 0.877, which was above the threshold 0.800 [32]; the comparative fit index (CFI) was 0.993, which was above the threshold 0.900 [29]; the normalized fit index (NFI) was 0.949, which was above the threshold 0.900 [29]; and finally, the root mean square error of approximation (RMSEA) was 0.027, which was below the threshold 0.050 [33]. Thus, each indicator of the goodness of fit in CFA was at an admissible level.

\begin{tabular}{llll}
\multicolumn{4}{c}{ TABLE IV: GOODNESS OF FIT FOR CONFIRMATORY FACTOR ANALYSIS } \\
\hline \hline Index & Criterion & Source & Adjusted Value \\
\hline CMIN/DF & $<3.000$ & Hair et al. (2010) & 1.151 \\
GFI & $\geq 0.900$ & Bagozzi and Yi (1988) & 0.900 \\
AGFI & $\geq 0.800$ & Filippini et al. (1998) & 0.877 \\
CFI & $\geq 0.900$ & Hair et al. (2006) & 0.993 \\
NFI & $\geq 0.900$ & Hair et al. (2006) & 0.949 \\
RMSEA & $<0.050$ & Browne and Cudeck (1993) & 0.027 \\
\hline \multicolumn{4}{c}{ Source: Created by the author. }
\end{tabular}

As summarized in Table IV, each value of Cronbach's Alpha exceeded 0.900, which demonstrated excellent associate internal consistency reliability of the results. Furthermore, all the factor loadings were above 0.800 (i.e. greater than the acceptable threshold 0.500), and the t-values were all more than $1.980, \mathrm{p}$-values under $0.050, \mathrm{CR}$ greater than 0.700, and AVE over 0.500 [34]. Consequently, all the estimates in this section were at an acceptable level.

TABLE V: CONFIRMATORY FACTOR ANALYSIS RESUlts, COMPOSITE RELIABILITY (CR), AND AVERAGE VARIANCE EXTRACTED (AVE)

\begin{tabular}{|c|c|c|c|c|c|c|c|c|}
\hline Latent Variable & $\begin{array}{l}\text { Source of Questionnaire } \\
\text { (Measurement Indicator) }\end{array}$ & Item & Factor Loading & SE & T-value & P-value & $\mathrm{CR}$ & AVE \\
\hline \multirow{6}{*}{$\begin{array}{l}\text { Perceived Ease of } \\
\text { Use }\end{array}$} & \multirow{6}{*}{ Sangjo et al. (2015) [35] } & PEOU1 & 0.945 & - & - & - & \multirow{6}{*}{0.965} & \multirow{6}{*}{0.821} \\
\hline & & PEOU2 & 0.865 & 0.045 & 21.126 & $* * *$ & & \\
\hline & & PEOU3 & 0.897 & 0.042 & 23.798 & $* * *$ & & \\
\hline & & PEOU4 & 0.922 & 0.039 & 26.364 & $* * *$ & & \\
\hline & & PEOU5 & 0.907 & 0.042 & 24.602 & $* * *$ & & \\
\hline & & PEOU6 & 0.898 & 0.043 & 23.802 & $* * *$ & & \\
\hline \multirow{5}{*}{$\begin{array}{l}\text { Perceived } \\
\text { Usefulness }\end{array}$} & \multirow{5}{*}{ Manzano et al. (2009) [36] } & PU1 & 0.919 & - & - & - & \multirow{5}{*}{0.953} & \multirow{5}{*}{0.804} \\
\hline & & PU2 & 0.896 & 0.047 & 21.278 & $* * *$ & & \\
\hline & & PU3 & 0.900 & 0.047 & 21.652 & $* * *$ & & \\
\hline & & PU4 & 0.862 & 0.050 & 19.430 & $* * *$ & & \\
\hline & & PU5 & 0.925 & 0.045 & 22.168 & $* * *$ & & \\
\hline \multirow{5}{*}{ Attitude } & \multirow{5}{*}{ Fokides (2017) [37] } & ATT1 & 0.907 & - & - & - & \multirow{5}{*}{0.967} & \multirow{5}{*}{0.830} \\
\hline & & ATT2 & 0.928 & 0.045 & 23.151 & $* * *$ & & \\
\hline & & ATT4 & 0.849 & 0.050 & 18.328 & $* * *$ & & \\
\hline & & ATT5 & 0.909 & 0.046 & 21.800 & $* * *$ & & \\
\hline & & ATT6 & 0.918 & 0.046 & 22.460 & $* * *$ & & \\
\hline \multirow{4}{*}{ Course Structure } & \multirow{4}{*}{ Harsasi \& Sutawijyay (2018) [20] } & CS1 & 0.905 & - & - & - & \multirow{4}{*}{0.946} & \multirow{4}{*}{0.813} \\
\hline & & $\mathrm{CS} 2$ & 0.925 & 0.050 & 22.193 & $* * *$ & & \\
\hline & & $\mathrm{CS} 3$ & 0.910 & 0.051 & 21.113 & $* * *$ & & \\
\hline & & CS4 & 0.862 & 0.053 & 18.502 & $* * *$ & & \\
\hline \multirow{5}{*}{ Satisfaction } & \multirow{5}{*}{$\begin{array}{l}\text { Al-Azawei \& Lundqvist (2015) } \\
\text { [38] }\end{array}$} & SAT1 & 0.841 & - & - & - & \multirow{5}{*}{0.930} & \multirow{5}{*}{0.726} \\
\hline & & SAT2 & 0.889 & 0.066 & 16.833 & $* * *$ & & \\
\hline & & SAT3 & 0.799 & 0.072 & 14.229 & $* * *$ & & \\
\hline & & SAT4 & 0.901 & 0.061 & 17.359 & $* * *$ & & \\
\hline & & SAT5 & 0.825 & 0.066 & 14.829 & $* * *$ & & \\
\hline
\end{tabular}

Source: Created by the author.

TABLE VI: DISCRIMINANT VALIDITY

\begin{tabular}{l|ccccc}
\hline \hline Construct & PEOU & PU & ATT & CS & SAT \\
\hline PEOU & $\mathbf{0 . 9 0 6}$ & & & & \\
PU & 0.401 & $\mathbf{0 . 8 9 7}$ & & & \\
ATT & 0.536 & 0.431 & $\mathbf{0 . 9 1 1}$ & & \\
CS & 0.384 & 0.416 & 0.448 & $\mathbf{0 . 9 0 2}$ & \\
SAT & 0.469 & 0.456 & 0.562 & 0.704 & $\mathbf{0 . 8 5 2}$ \\
\hline \hline \multicolumn{7}{c}{ Source: Created by the author. }
\end{tabular}

For discriminant validity, the values were all at an ideal level, as presented in Table V. Accordingly, the convergent and discriminant validity were verified. Therefore, the matrix estimation results also facilitated discriminant validity and verification to estimate the validity of the subsequent SEM evaluation.

\section{Structural Equation Model (SEM)}

After CFA, SEM was applied to evaluate the specific system with a linear equation for the particular system to verify the fit of the hypothesized causal matrix. Further, SEM confirmed the casual relationship among the latent variables in a specific statistical matrix that evaluated accuracy or faithfulness according to the correlated coefficient [39]. Table VI shows the results adjusted by AMOS version 18.0. 
The criteria for CMIN/DF, GFI, AGFI, CFI, and RMSEA were equal to $\mathrm{CFA}$, and all the justified consequences were matched with the acceptable standards. Further, the value for the Tucker Lewis Index (TLI) was 0.991, also greater than the threshold 0.900 [29]. Accordingly, every indicator of the goodness of fit in the SEM evaluation was ideal.

TABLE VII: GOODNESS OF FIT FOR THE STRUCTURAL EQUATION MODEL

\begin{tabular}{llll}
\hline \hline Index & Criterion & Source & $\begin{array}{l}\text { Adjusted } \\
\text { Values }\end{array}$ \\
\hline CMIN/DF & $<3.000$ & Hair et al. $(2010)$ & 1.163 \\
GFI & $\geq 0.900$ & Bagozzi and Yi (1988) & 0.901 \\
AGFI & $\geq 0.800$ & Filippini et al. $(1998)$ & 0.876 \\
CFI & $\geq 0.900$ & Hair et al. $(2006)$ & 0.993 \\
TLI & $\geq 0.900$ & Hair et al. (2006) & 0.991 \\
RMSEA & $<0.050$ & Browne and Cudeck (1993) & 0.028 \\
\hline \hline \multicolumn{4}{c}{ Source: Created by the author }
\end{tabular}

\section{Hypothesis Testing Results}

The research matrix was calculated as the significance for each latent variable from the regression weights and $R^{2}$ variances. As Table VII shows, CS exerted the greatest effect on satisfaction, with a standard path coefficient $(\beta)$ of 0.654 and $\mathrm{t}$-value of $10.544 * * *$. Attitude was another factor that directly influenced satisfaction, with $\beta=0.344$ and $\mathrm{t}$-value $=$ $6.366^{* * *}$. Moreover, PEOU affected attitude with $\beta=0.570$ and $t$-value $=7.188^{* * *}$, and this factor impacted PU with $\beta=$ 0.409 and $\mathrm{t}-\mathrm{value}=6.241^{* * * *}$. Finally, PU influenced attitude with $\beta=0.246$ and $t$-value $=3.871^{* * *}$. Therefore, all the hypotheses were supported at the level of significance as the p-values were less than 0.001 .

Furthermore, the following conclusions can be drawn from the results of the data analysis. The findings related to $\mathrm{H} 1$ showed that PEOU affected PU with a standardized path coefficient value of 0.409 for the structure mechanism. Sangjo and colleagues confirmed that PEOU enhanced students' positive and active estimation of PU in the blended instruction system [35].

In terms of $\mathrm{H} 2$, the results demonstrated that PU was a key factor of attitude, with a standardized path coefficient value of 0.246. Manzano and other experts explained that PU is an essential index for student satisfaction with hybrid education [36].

Then, concerning $\mathrm{H} 3$, the results indicated that PEOU essentially influenced attitude, with a standardized path coefficient value of 0.570 , which was the second greatest impact. Rui-Hsin and Lin determined that PEOU exerted a key effect on students' attitude toward the utilization of a learning system for a particular instructional approach [40].

In addition, regarding $\mathrm{H} 4$, attitude showed an influence on satisfaction with a standardized path coefficient value of 0.344. According to Fokides, attitude is a predominant psychological indicator of students' satisfaction associated with blended instruction [37].

Finally concerning H5, the results demonstrated that CS was extremely influential on satisfaction with a standardized path coefficient value of 0.654 , making it the factor with the strongest influence on the independent variable. Al-Azawei and Lundqvist confirmed that CS is the most essential influencer on student satisfaction with a particular instruction type [20].

TABLE VIII: SEM RESULTS RELATED TO THE STUDY HYPOTHESES

\begin{tabular}{llllllll}
\hline \hline Hypotheses & & Path & & Standardized Path Coefficient $(\beta)$ & SE & T-Value & Test Results \\
\hline H1 & PU & $\leftarrow$ & PEOU & 0.409 & 0.064 & $6.241^{* * * *}$ & Supported \\
H2 & ATT & $\leftarrow$ & PU & 0.246 & 0.064 & $3.871^{* * * *}$ & Supported \\
H3 & ATT & $\leftarrow$ & PEOU & 0.570 & 0.064 & $7.188^{* * * *}$ & Supported \\
H4 & SAT & $\leftarrow$ & ATT & 0.344 & 0.042 & $6.366^{* * *}$ & Supported \\
H5 & SAT & $\leftarrow$ & CS & 0.654 & 0.051 & $10.544^{* * *}$ & Supported \\
\hline \hline
\end{tabular}

Source: Created by the author

\section{CONCLUSIONS AND RECOMMENDATIONS}

\section{A. Conclusions}

This study aimed at identifying significant factors influencing student satisfaction with blended instruction in the professional core course "Digital Image Fundamental" for animation major undergraduate students at Chengdu University. Five hypotheses were proposed as a conceptual framework to examine how PEOU, PU, attitude, and CS significantly affected student satisfaction. The quantitative questionnaires were distributed to 210 animation major undergraduate students who had taken the target course with blended instruction. CFA was employed to verify the correlated validity and reliability with regard to the conceptual framework. The predominant influencers that influenced satisfaction were examined by SEM.

The results showed that CS had the greatest effect on student satisfaction with blended instruction in the "Digital Image Fundamental" course. Therefore, it is important for instructors to establish a reasonable CS for animation professional courses by appropriately utilizing the characteristics of blended education.

In addition, attitude had a significant effect on satisfaction. This accords with the findings of Dabholkar and Bagozzi, who showed that students' positive attitude toward using hybrid education generated a vital, active effect on their satisfaction, which, in turn, made active and positive contributions to their learning achievements [41].

Both PEOU and PU were shown to have a significant influence on students' attitude toward using the blended education system. Additionally, PEOU had a significant influence on PU. These findings support those of Davis, who confirmed a relationship among such variables as well. The PEOU and PU of hybrid education can contribute to students' positive learning attitude [8]. 
In general, the objectives of this research were accomplished: namely, PEOU, PU, attitude, and CS were revealed as key influencers of student satisfaction with blended instruction in the target course for animation majors at Chengdu University.

\section{B. Recommendations}

This research analyzed the key influencers of satisfaction among undergraduate students at Chengdu University. Annamdevula and Bellamkonda argued that student satisfaction is one of the most vital influencers in effective learning [24]. Based on our findings, recommendations can be made for instructors to improve course design and blended instruction in order to achieve a greater quality of education by focusing on student satisfaction.

Instructors should emphasize the design of the CS and provide assistance for students to use hybrid education platforms. Firstly, they need to reduce students' unfamiliarity and resistance to online instructional platforms for blended instruction. Teaching courseware and multimedia materials for the animation professions should be integrated into the internet learning platform as the main content of the course as well as supplementary resources. Instructors should guide students appropriately to achieve satisfaction with their blended learning experiences, particularly regarding the PEOU and PU of blended approaches, in order to build students' positive attitudes toward hybrid education.

Furthermore, instructors should design suitable learning plans of blended instruction according to the needs and characteristics of animation professionals. Finally, given the combined effects of PEOU, PU, attitude, and CS, instructors should seek to improve student satisfaction with blended learning experiences in order to facilitate satisfactory learning performance.

\section{Limitations and Further Research}

A limitation of this study is that the target population included only students at Chengdu University. Moreover, only one professional core course was selected for the quantitative analysis.

Further exploration can take place in two parts. First, the research scope can be extended to other representative courses in animation or fine art design majors and possibly to universities in other regions of China. Second, the investigation can consider other latent variables, such as behavioral intention, social influence, self-efficacy, effort expectancy, trust, perceived interaction, learning motivation, performance expectancy, and facilitating conditions, in order to the extend the research framework on the conceptual structure of student satisfaction with blended learning.

\section{CONFLICT OF INTEREST}

The author declares no conflict of interest.

\section{AUTHOR CONTRIBUTIONS}

For this article, Xiang Chaochu and Somsit Duangekanong constructed the research method and framework. In additional Xiang Chaohu was responsible for Introduction, literature review, and methodology, Somsit Duangekanong was responsible for results, discussions, and conclusions.

\section{REFERENCES}

[1] A. Doering, "Adventure learning: Transformative hybrid online education," Distance Education, vol. 27, no. 2, pp. 197-215, 2006.

[2] J. C. Rivera, M. K. McAlister, and M. Rice, "A comparison of student outcomes \& satisfaction between traditional \& web-based course offerings," Online Journal of Distance Learning Administration, vol. 5, no. 3, pp. 151-179, 2002.

[3] C. Xiang, "The current issue of the digital game concept art education for Chinese undergraduates," International Journal of Information and Education Technology, vol. 9, no. 6, pp. 419-422, 2019.

[4] B. Mansour and D. M. Mupinga, "Students' positive and negative experiences in hybrid and online classes," College Student Journal, vol. 41, no. 1, pp. 242-248, 2007.

[5] J. Popma, "Is hybrid education and videoconferencing the wave of the future for online courses?" Journal of Instructional Research, vol. 1, pp. 67-72, 2012.

[6] J. C. Rivera, M. K. McAlister, and M. Rice, "A comparison of student outcomes \& satisfaction between traditional \& web-based course offerings," Online Journal of Distance Learning Administration, vol. 5, no. 3, pp. 151-179, 2002.

[7] M. Zhang and H. Du, "Analysis on the actuality and research tendency of hybrid education" The Chinese Journal of ICT in Education, vol. 1, no. 1 , pp. $84-85,2020$.

[8] F. D. Davis, "Perceived usefulness, perceived ease of use, and user acceptance of information technology," MIS Quarterly, vol. 13, no. 3, pp. 319-340, 1989

[9] M. Neo, H. Park, M. Lee, J. Soh, and J. Oh, "Technology acceptance of healthcare e-learning modules: A study of Korean and Malaysian students' perceptions," Turkish Online Journal of Educational Technology, vol. 14, no. 2, pp. 181-194, 2015.

[10] C. Qin, Y. Liu, J. Mou, and J. Chen, "User adoption of a hybrid social tagging approach in an online knowledge community," Aslib Journal of Information Management, vol. 71, no. 2, pp. 155-175, 2019.

[11] V. Venkatesh, "Determinants of perceived ease of use: Integrating perceived behavioral control, computer anxiety and enjoyment into the technology acceptance model," Information Systems Research, vol. 11, no. 4 , pp. $342-365,2000$

[12] M. Lee, "Factors influencing the adoption of internet banking: An integration of TAM and TPB with perceived risk and perceived benefit," Electronic Commerce Research and Applications, vol. 8, no. 3, pp. 130-141, 2009.

[13] P. Vululleh, "Determinants of students' e-learning acceptance in developing countries: An approach based on structural equation modeling (SEM)," International Journal of Education and Development Using Information and Communication Technology, vol. 14, no. 1, pp. 141-151, 2018.

[14] C. Ong and J. Lai, "Gender differences in perceptions and relationships among dominants of e-learning acceptance," Computers in Human Behavior, vol. 22, no. 5, pp. 816-829, 2006

[15] H. R. Chen and H. F. Tseng, "Factors that influence acceptance of web-based e-learning systems for the in-service education of junior high school teachers in Taiwan," Evaluation and Program Planning, vol. 35, no. 3, pp. 398-406, 2012

[16] J. T. Nagy, "Evaluation of online video usage and learning satisfaction: An extension of the technology acceptance model," International Review of Research in Open and Distributed Learning, vol. 19, no. 1, pp. 160-184, 2018

[17] I. Ajzen, "The theory of planned behavior," Organizational Behavior and Human Decision Processes, vol. 50, no. 2, pp. 179-211, 1991.

[18] W. R. King and J. He, "A meta-analysis of the technology acceptance model," Information and Management, vol. 43, no. 6, pp. 740-755, 2006.

[19] A. Bahjat, "Attitudes towards using mobile applications in teaching mathematics in open learning systems," International Journal of E-Learning and Distance Education, vol. 33, no. 1, pp. 2-16, 2018.

[20] M. Harsasi and A. Sutawijaya, "Determinants of student satisfaction in online tutorial: A study of a distance education institution," Turkish Online Journal of Distance Education, vol. 19, no. 1, pp. 89-99, 2018

[21] M. Paechter, B. Maier, and D. Macher, "Students' expectations of, and experiences in e-learning: Their relation to learning achievements and course satisfaction," Computers and Education, vol. 54, no. 1, pp. 222-229, 2010.

[22] H. M. Selim, "Critical success factors for e-learning acceptance: Confirmatory factor models," Computers and Education, vol. 49, no. 2, pp. 396-413, 2007.

[23] E. A. Locke, "What is job satisfaction?" Organizational Behavior and Human Performance, vol. 4, no. 4, pp. 309-336, 1969. 
[24] S. Annamdevula and R. S. Bellamkonda, "The effects of service quality on student loyalty: The mediating role of student satisfaction," Journal of Modelling in Management, vol. 11, no. 2, pp. 446-462, 2016.

[25] H. Cigdem and M. Ozturk, "Factors affecting students' behavioral intention to use LMS at a Turkish post-secondary vocational school," International Review of Research in Open and Distributed Learning, vol. 17, no. 3, pp. 276-295, 2016.

[26] S. Isaac and W. B. Michael, Handbook in Research and Evaluation: A Collection of Principles, Methods, and Strategies Useful in the Planning, Design, and Evaluation of Studies in Education and the Behavioral Science, 3rd ed. San Diego, CA: Edits Publishers Press, 1995.

[27] V. Halabíand R. More-Espuivel, "Sample sizes using structural equation modeling with latent variables: A practical method," Actualidades Investigativas en Educación, vol. 17, no. 1, pp. 1-34, 2017.

[28] M. Lewis-Beck, A. Bryman, and T. Liao, Encyclopedia of Social Science Research Methods, Thousand Oaks, CA: Saga Publications, 2004.

[29] J. F. Hair, W. C. Black, B. J. Babin, R. E. Anderson, and R. L. Tatham, Multivariant Data Analysis, Pearson, International ed., 2006.

[30] J. F. Hair, R. E. Anderson, R. L. Tatham, and W. C. Black, Multivariate Data Analysis, 6th ed. Upper Saddle River, NJ: Prentice Hall, 2010.

[31] R. P. Bagozzi and Y. Yi, "On the evaluation of structural equation models," Journal of the Academy of Marketing Science, vol. 16, no. 1, pp. 74-94, 1988.

[32] R. Filippini, C. Forza, and A. Vinelli, "Trade-off and compatibility between performance: Definitions and empirical evidence," International Journal of Production Research, vol. 36, no. 12, pp. 3379-3406, 1998.

[33] W. Browne and R. Cudeck, "Alternative ways of assessing model fit," Testing Structural Equation Models, Newbury Park, CA: SAGE, 1993.

[34] R. Sarmento and V. Costa, Comparative Approaches to Using R and Python for Statistical Data Analysis, IGI Global Press, 2016.

[35] O. Sangjo, A. Joongho, and K. Beomsoo, "Adoption of broadband Internet in Korea: The role of experience in building attitudes," Journal of Information Technology, vol. 18, pp. 267-280, 2015.

[36] J. Aldás-Manzano, C. Lassala-Navarré, C. Ruiz-Mafé, and S. Sanz-Blas, "Key drivers of internet banking services use," Online Information Review, vol. 33, no. 4, pp. 672-695, 2009.

[37] E. Fokides, "Greek pre-service teachers' intentions to use computers as in-service teachers," Contemporary Educational Technology, vol. 8, no 1, pp. 56-75, 2017.

[38] A. Al-Azawei and K. Lundqvist, "Learner differences in perceived satisfaction of an online learning: An extension to the technology acceptance model in an arabic sample, learner differences in perceived satisfaction of an online learning: An extension to the technology acceptance model in an Arabic sample," Electronic Journal of e-Learning, vol. 13, no. 5, pp. 408-426, 2015.
[39] T. Jaruwanakul, "Key influencers of innovative work behavior in leading Thai property developers," AU-GSB E-Journal, vol. 14, no. 1, pp. 61-70, 2021.

[40] K. Rui-Hsin and C. Lin, "The usage intention of e-learning for police education and training," Policing, vol. 41, no. 1, pp. 98-112, 2018.

[41] P. A. Dabholkar and R. P. Bagozzi, "An attitudinal model of technology-based self-service: Moderating effects of consumer traits and situational factors," Journal of the Academy of Marketing Science, vol. 30, no. 3, pp. 184-201, 2002.

Copyright $(\odot) 2022$ by the authors. This is an open access article distributed under the Creative Commons Attribution License which permits unrestricted use, distribution, and reproduction in any medium, provided the original work is properly cited (CC BY 4.0).

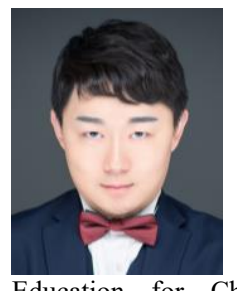

Xiang Chaochu is a Ph.D. candidate in teaching and technology at Assumption University of Thailand and an associate professor at Chengdu University. Professor Xiang's main areas of research include teaching and technology, animation anthropology, animation sociology, and the animation industry. His recent academic publications are as follows: "The Current Issue of the Digital Game Concept Art Education for Chinese Undergraduates," International Journal of Information and Education Technology, vol.9(6), pp. 419-422, 2019; "The Characteristics and Harm of Militarism Thoughts in Japanese Animation," International Journal of Learning and Teaching, vol.5(2), pp. 145-148, 2019; "An Analysis of Japanese Otaku Culture from a Viewpoint of Animation Anthropology," International Journal of Learning and Teaching, vol.5(3), pp. 275-279, 2019; "Reflections on the Joint Cultivation of Undergraduate Animation Education in China and Thailand," International Journal of Learning and Teaching, vol. 6(2), pp. 129-134, 2020; and "Research on the Construction of Chinese Undergraduate Comic Major," International Journal of Learning and Teaching, vol. 6(4), pp. 257-261, 2020.

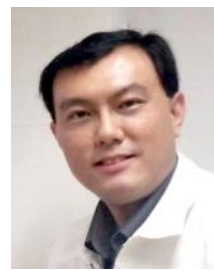

Somsit Duangekanong is the program director for Ph.D. technology education management of the Graduate School of Business and Advanced Technology Management, Assumption University of Thailand. Dr. Somsit is a Ph.D. faculty member of Ph.D. technology education management, Ph.D. innovative technology management, and Ph.D. teaching and technology. His research areas are information project management, business strategy and innovation, and advanced research. 